\title{
EDITORIAL
}

\section{Indian Journal of Medical Ethics - retrospect and prospect}

\section{SUNIL K PANDYA}

As the Indian Journal of Medical Ethics (IJME) nears the age of thirty years, it is well to undertake a review of its performance.

\section{The beginnings}

When this journal first saw the light of day in the form of a small newsletter with the simple title Medical Ethics, its survival was in doubt. Ethics was not even a blip on the horizon for most of those involved in healthcare and the treatment of patients.

I can state from personal observation and experience since my days as a medical student in 1957 that probity was the rule among members of the medical profession in the 1940s and 1950s. The rot set in a little later, when a senior consultant in Bombay decided to expand his practice and income by bribing family physicians and other medical doctors to send patients to him. As with most lapses in morals, this soon spread within the profession and later involved a wide range of other agencies including the pharmaceutical industry.

In the 1980s, the medical profession defied attempts at injecting accountability into its activities. An excellent example is the vociferous campaign against the Consumer Protection Act. Their efforts at annulling it did not succeed in court. When political changes made profit-making by industry respectable, corporate hospitals and doctors found common ground with commerce.

There were protests against unethical practices from time to time, and an irregular series of essays on unethical practices in India appeared from 1968 in diverse Indian and foreign publications; but these failed to herald any improvement. A general decline in character in our country was reflected in members of the medical profession. This was one of the factors leading to a blatant neglect of voices preaching ethics.

An unscheduled conversation, during a tea break at a meeting at the Tata Institute of Social Sciences, in August 1992, changed the situation. As a group of physicians and social activists, including members of Maharashtra Association of Resident Doctors (MARD), Medico-Friends Circle (MFC) and Association for Consumers Action on Safety and Health (ACASH), sat chatting about the unethical practices in the medical profession, someone made a pregnant comment: "Why do you keep talking on this issue? Why don't you do something about it?". Thus provoked, this group formed the Forum for Medical Ethics whose founder members were Sunil K Pandya, Amar Jesani, Sanjay Nagral, Manohar Kher, Santosh Karmarkar, Arun Bal, Anil K Pilgaokar, and Manohar Kamath. The urgent provocation was the impending election of members of the Maharashtra Medical Council. A detailed account of how the group attempted to enter the Council has been provided by Dr Manohar Kamath in the first essay in the first issue of this journal (1).

Initial activities of the Forum focused on promoting discussions on medical ethics, malpractices and corrective measures in periodic meetings. Another means for achieving these ends was the production of a newsletter Medical Ethics, which would communicate the principles and practice of ethics to the medical profession and to students in our medical colleges. It would also serve as a regular platform for discussion. 'Why is this newsletter necessary?' in the first issue provides details (2).

Over time, these activities and the newsletter progressed, the latter being renamed first as Issues in Medical Ethics and then Indian Journal of Medical Ethics. However, the impact of the Forum's activities remained sub-optimal.

The need had long been expressed for expansion of our membership and the involvement of greater numbers of medical and paramedical professionals and social scientists.

Eventually, all these efforts began to bear fruit in 2005, and the journal was indexed in Medline, with retrospective effect from its inception in 1993. In the same year, the First National Bioethics Conference (NBC) was organised. Its goals were clearly enunciated: 'development of bioethics as a major healthcare concern and a discipline... to increase awareness and sensitivity in the research and practice of bioethics; to increase debates, discussions, interactions and publications in the field; to sensitise

Author: Sunil K Pandya (shunil3@gmail.com), (Retd) Department of Neurosurgery, Jaslok Hospital and Research Centre, Deshmukh Marg, Mumbai, INDIA; Editor Emeritus and Founder Editor, Indian Journal of Medical Ethics, Mumbai, INDIA.

To cite: Pandya SK. Indian Journal of Medical Ethics - retrospect and prospect. Indian J Med Ethics. 2022 Jan-Mar; 7(1) NS: 3-4. DOI: 10.20529/IJME.2022.001.

(c) Indian Journal of Medical Ethics 2022 
multidisciplinary actors from health, social sciences and humanities discipline; and to create platforms to nurture the growth of bioethics.'(3)

Subsequent National Bioethics Conferences have brought the Forum and its activities to prominence in the national and international arenas, increasing the engagement of young researchers and practitioners in the bioethics movement. A wide range of topics is now discussed there and corrective measures proposed to improve both the practice of medicine and healthcare in general and for deprived people in particular. The 8th National Bioethics Conference, held online in 2020, focused on the theme "Crisis within a crisis: the scientific, ethical and humanitarian challenge of COVID-19."

The Forum has added another arm - Health, Ethics and Law (HEaL) Institute - to focus attention, and carry out advocacy and research on ethical and humanitarian deficiencies.

This journal has grown in strength thanks to its successive editors such as Drs Arun Bal, Samiran Nundy, Sanjay A Pai, George Thomas and, now, Amar Jesani. Over these years, it has gained international reputation. Current submissions of papers to it are almost equally divided between those from India and those from abroad. The journal website also has a substantial readership in the subcontinent and well beyond.

The survival and progress of the Forum and its journal in the face of persistent professional indifference to ethical reform are noteworthy. The journal has not succumbed to market pressure. It has retained its economic independence and devotion to its mission by abjuring advertisements from the medical industry, and resisting moves by professional publishers to take over its production.

\section{Much remains to be done}

All of us are well aware that though we have made some progress, much remains to be done. Ethical misconduct continues, guidelines set up after much thought on a variety of procedures and practices remain on paper, and there is little reason for miscreants to fear corrective action. Agencies intended to monitor and discipline medical and health practices lack autonomy, show little or no transparency and continue to be ineffective, degraded and subject to interference by politicians. The sordid example of the Medical Council of India with Dr Ketan Desai as its head remains fresh in memory (4). National and state policies are dictated more by political compulsions than reason. The manner in which the Covid-19 epidemic has been handled is an example.

\section{The future}

The Forum and the journal, now with a considerably larger network of dedicated individuals from a variety of disciplines, can deal with these and other problems with greater confidence than did the handful of well-meaning persons that started out 30 years ago.

We also have close relationships with international experts and agencies that will stand us in good stead as we go about our task of restoring good practices and better sense in the field of public health. Our people deserve these, especially those in dire straits, in villages and tribal settlements.

\section{Award for Bioethics to Dr Amar Jesani}

The Forum and the movement on bioethics in India have received a shot in the arm from the announcement by the International Association of Bioethics of the 2021 Award for Bioethics Service in the Face of Challenges to Dr Amar Jesani." The award recognizes individuals who have championed local, national, and/or international efforts, sustained over a period of time, that advance bioethics or put bioethics into action, mobilizing knowledge into impact, and doing so in the face of challenges." Vardit Ravitsky, Professor at the University of Montreal and President of the Board of Directors of the Association, added: "Amar's record - spanning medical ethics, public health ethics, and research ethics - is a shining example of the bioethics work that this award is meant to recognize."

The award recognises what we already knew and in doing so, the IAB acknowledges the eclectic nature of the Indian bioethics movement and Amar Jesani's contribution to it.

\section{References}

1. Kamath MS. Elections; The true story. Med Ethics. 1993 Aug-Oct [cited 2021 Dec 25]; 1(1): 1-3. . Available from: https://ijme.in/articles/elections-thetrue-story/

2. Editorial Team. A brief note on THE FORUM FOR MEDICAL ETHICS (FME). Med Ethics. 1993 Aug-Oct[cited 2021 Dec 25];1(1): 3.Available from: https:// ijme.in/articles/a-brief-note-on-the-forum-for-medical-ethics-fme/"

3. Jesani A. Conference objectives and structure. Indian J Med Ethics. 2005 Supplement [cited 2021 Dec 28]; 2: S-5. Available from: https://ijme.in/nbc20140321/pdf/nbc1/nbc-2005-supplement-issue.pdf

4. Chauhan N. Ex-MCl chief Ketan Desai took Rs 2 crore as bribe: CBI. Times of India. 2011 Sep 20[cited 2021 Dec 23]. Available from: https:// timesofindia.indiatimes.com/india/Ex-MCl-chief-Ketan-Desai-took-Rs-2-crore-as-bribe-CBI/articleshow/10046462.cms 